\title{
Trace Elements and Carbon and Nitrogen Stable Isotopes in Organisms from a Tropical Coastal Lagoon
}

\author{
A. A. Pereira $\cdot$ B. van Hattum $\cdot$ J. de Boer $\cdot$ \\ P. M. van Bodegom • C. E. Rezende • \\ W. Salomons
}

Received: 19 November 2009/Accepted: 10 February 2010/Published online: 10 March 2010

(C) The Author(s) 2010. This article is published with open access at Springerlink.com

\begin{abstract}
Trace elements (Fe, $\mathrm{Mn}, \mathrm{Al}, \mathrm{Zn}, \mathrm{Cr}, \mathrm{Cu}, \mathrm{Ni}, \mathrm{Pb}$, $\mathrm{Cd}, \mathrm{Hg}$, and As) and stable isotope ratios $\left(\delta^{13} \mathrm{C}\right.$ and $\left.\delta^{15} \mathrm{~N}\right)$ were analyzed in sediments, invertebrates, and fishes from a tropical coastal lagoon influenced by iron ore mining and processing activities to assess the differences in trace element accumulation patterns among species and to investigate relations with trophic levels of the organisms involved. Overall significant negative relations between trophic level (given by ${ }^{15} \mathrm{~N}$ ) and trace element concentrations in gastropods and crustaceans showed differences in internal controls of trace element accumulation among the species of different trophic positions, leading to trace element dilution. Generally, no significant relation between $\delta^{15} \mathrm{~N}$ and trace element concentrations was observed among fish species, probably due to omnivory in a number of species as well as fast growth. Trace element accumulation was observed in the fish tissues, with higher levels of most trace elements found in liver compared with muscle and gill. Levels of $\mathrm{Fe}, \mathrm{Mn}, \mathrm{Al}$, and $\mathrm{Hg}$ in invertebrates, and $\mathrm{Fe}$ and $\mathrm{Cu}$ in fish livers, were comparable with levels in organisms and tissues from other contaminated areas.
\end{abstract}

\footnotetext{
A. A. Pereira $(\varangle) \cdot$ B. van Hattum · J. de Boer · W. Salomons Institute for Environmental Studies, VU University,

De Boelelaan 1087, 1081 HV Amsterdam, The Netherlands e-mail: adriana.pereira@ivm.falw.vu.nl;

adriana.pereira@ivm.vu.nl

P. M. van Bodegom

Department of Systems Ecology, VU University,

De Boelelaan 1085, 1081 HV Amsterdam, The Netherlands

\section{E. Rezende}

Centro de Biociências e Biotecnologia, Laboratório de Ciências Ambientais, Universidade Estadual do Norte Fluminense, Alberto Lamego 2000, CEP 28013-600 Campos dos Goytacazes, Rio de Janeiro, Brazil
}

Trace element levels in fish muscle were below the international safety baseline standards for human consumption.

Coastal lagoons are inland shallow water bodies, usually oriented parallel to the coast and connected to the ocean by one or more restricted inlets (Kjerfve 1994). They occupy approximately $13 \%$ of the total coastal zone on the planet, including approximately $10 \%$ of the coast of South America (Barnes 1980), and are abundant along the Brazilian coast. They are often impacted by both natural and anthropogenic influences (Mee 1978), functioning as filters or material sinks of organic and inorganic material supplied by rivers, adjacent soils, the atmosphere, and the ocean for long periods of time (Kjerfve and Magill 1989). In this context, coastal lagoons may be sensitive to chemical contamination mainly due to their relative shallowness, long residence times, and restricted water exchange (Lacerda 1994).

Trace elements, whether of natural or anthropogenic origin, are present in all ecosystems throughout the world. At high levels, trace elements are potentially toxic and may disrupt biologic activities of aquatic ecosystems (Asante et al. 2008), and may also bioaccumulate in the local organisms. Bioaccumulation of trace elements is a complex phenomenon controlled by a large number of physiologic and environmental factors. Patterns of trace element accumulation differ largely among species and trophic position, depending on specific regulatory mechanisms of body concentrations (Luoma and Rainbow 2005; Rainbow 2007).

Trophic relations in coastal lagoon food webs are particularly complex because of the involvement of a high number of primary producers, a variety of detrital food chains, and a high degree of interconnectedness (Knoppers 
1994; Alongi 1998). In addition to information on an organism's diet and analysis of gut contents, stable isotope ratios $\left(\delta^{13} \mathrm{C}\right.$ and $\left.\delta^{15} \mathrm{~N}\right)$ have been used to provide additional information on the trophic level of organisms, food web structure, and organic matter pathways (Minagawa and Wada 1984; Michener and Schell 1994; France 1995). Therefore, $\delta^{15} \mathrm{~N}$ can be used as an indicator of trophic levels of organisms in food chains, and $\delta^{13} \mathrm{C}$ can be used to indicate relative contributions to the diet of different potential primary carbon sources in a trophic network. Moreover, the consistency of $\delta^{15} \mathrm{~N}$ enrichment at each trophic level may be correlated with contaminant concentrations and has been used in numerous studies to estimate trophic transfer of trace elements in aquatic food webs (McIntyre and Beauchamp 2007; Marin-Guirao et al. 2008; Ikemoto et al. 2008; Asante et al. 2008; Watanabe et al. 2008; Sharma et al. 2008). These studies have shown that specific trace elements sometimes biomagnify, biodilute, or do not change concentrations along food webs. The lack of a clear pattern of trophic transfer among food chains is probably determined by the trace element accumulation pattern of the particular species involved and on the biologic role of each element (Rainbow 2002; Wang 2002). However, most of the studies available are focused on food webs from temperate areas. Information about trophic transfer and trace element accumulation patterns of species from tropical aquatic food webs still remains scarce.

This study aimed to assess trace element accumulation features (Fe, Mn, Al, Zn, Cr, Cu, Ni, Pb, Cd, Hg, and $\mathrm{As}$ ) in biota (invertebrates and fishes) from a tropical coastal lagoon that receives effluents from iron ore mining and processing activities located in southeastern Brazil. $\mathrm{C}$ and $\mathrm{N}$ isotopic ratios were used to investigate the relation between accumulation of trace elements and trophic levels in the lagoon ecosystem. To assess if anthropogenic inputs affect stable isotopes signatures and trace element levels in the lagoon, trace element concentrations were also compared with those from biota of surrounding regions. Moreover, tissue variations in fish species were evaluated to test for potential risks to human health.

\section{Materials and Methods}

\section{Study Area}

Mãe-Bá Lagoon is a freshwater coastal lagoon that receives the final effluents from an iron ore mining and pelletizing plant, named Samarco Mineração S/A, located in southeastern Brazil. Samarco has two industrial sites (Fig. 1): a mining complex with a concentration plant, located in the district of Mariana, Minas Gerais State (Germano site) and a pelletizing plant with port facilities, located in the district of Anchieta, Espírito Santo State (Ponta Ubu site). At the mining complex, effluents with high content of solids are produced and treated in two settling dams, named Germano and Santarém. The treated effluents flow to Santarém Creek and reach Gualaxo do Norte River, which is part of the Doce River hydrographic basin. A pipeline (396-km long) transports the ore mixed with water (i.e., slurry) to the pelletizing plant. In this plant, the ore is separated from the water, and the effluent flows to an artificial lake (North Dam). Seasonally during high rainfall, this artificial lake overflows into Mãe-Bá Lagoon. Mãe-Bá Lagoon is a coastal lagoon without a direct surface connection to the sea. It has an area of $5.0 \mathrm{~km}^{2}$ and an average depth of

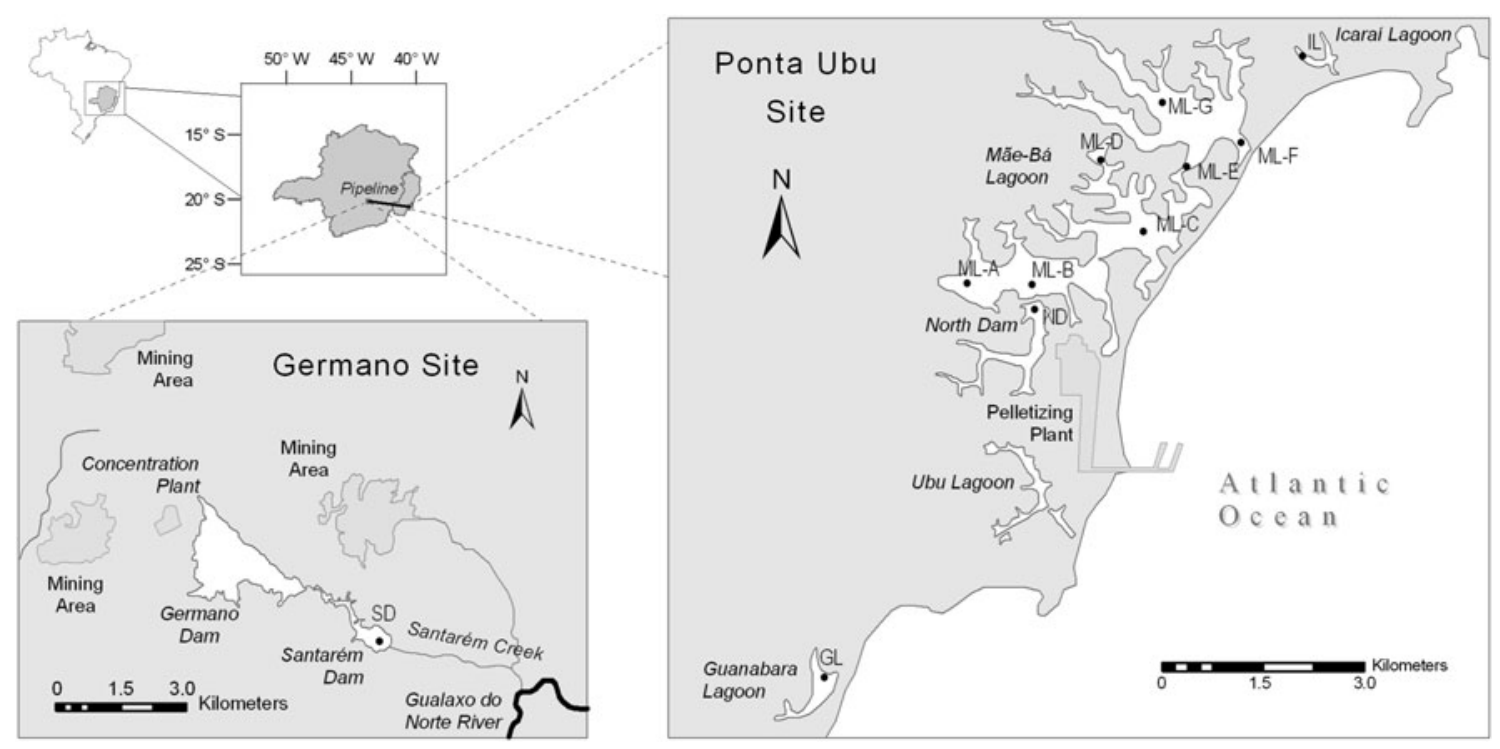

Fig. 1 Map showing the studied area and position of the sampling sites 
$1.9 \mathrm{~m}$. The lagoon also receives untreated sewage and represents an important source of animal protein for the local population.

\section{Site Selection}

Invertebrates and sediments were collected simultaneously at seven locations at Mãe-Bá Lagoon (sites ML-A to ML-G, Fig. 1). For fish sampling, sites were grouped according to three regions, named ML-AB (region closer to North Dam), ML-CDE (located in the middle part of the lagoon), and ML-FG (region far from North Dam). When available, organisms from the tailing dam (Santarém Dam, site SD) and from the artificial lake (North Dam, site ND) were also collected, to assess the direct influence of the iron ore mining and processing on biota. In addition, two nearby coastal lagoons (Icaraí [site IL] and Guanabara Lagoons [site GL]), which do not receive effluents from industrial process, were included as comparison sites.

\section{Sediments}

At each site, sediments were collected as substrates of invertebrates. The number of sediment samples depended on type of substrate and species found at each site (Melanoides tuberculata and Macrobrachium sp., for example, were caught in 2 different substrates at sites ML-C, ML-F, and ML-G). In total, 10 sediment samples were collected at Mãe-Bá Lagoon (see Table 1 for distribution of number of samples per site), and 3 samples were collected from the surrounding areas. Each sediment sample was transferred to a plastic bag and kept on ice in the field. In the laboratory, individual samples were sieved in a $2-\mathrm{mm}$ stainless steel sieve to remove gravel particles and large detritus and then oven dried at $50^{\circ} \mathrm{C}$ to constant weight. After drying, samples were ground in a marble mortar with a pestle, identified, and stored in polyethylene bags. Aqua regia (4 mL $\mathrm{HNO}_{3} 70.5 \%$ [Ultrex; J. T. Baker, Canada] and $12 \mathrm{~mL} \mathrm{HCl} \mathrm{37 \%} \mathrm{[Instra-Analyzed;} \mathrm{J.} \mathrm{T.} \mathrm{Baker,} \mathrm{Phillips-}$ burg, $\mathrm{NJ}]$ ) was added to an aliquot of $0.5 \mathrm{~g}$ dry weight (dw) and left at room temperature overnight. Afterward, samples were digested in a microwave sample preparation system (MDS-2000 at $1920 \mathrm{~W}$; CEM, Mathews, NC) with 0 to $100 \%$ full power $(630 \mathrm{~W})$ capability adjustable in $1 \%$ increments. For 12-position sample carousel, 5 sequential stages of varying power and time intervals were programmed: (1) $30 \%$ power, 100 PSI, 4 minutes; (2) $80 \%$ power, 120 PSI, 4 minutes; (3) 100\% power, 170 PSI, 20 minutes; (4) 50\% power, 170 PSI, 6 minutes; (5) no power, no pressure, 15 minutes. Fumes from acidified sediment extracts were released using $\mathrm{N}_{2}(\mathrm{~g})$ to avoid spectral interference of $\mathrm{HNO}_{3}$ with $\mathrm{Hg}$ analysis. Samples were finally diluted to $100 \mathrm{~mL}$ with distilled deionized water. Analyses of $\mathrm{Fe}, \mathrm{Mn}, \mathrm{Al}, \mathrm{Zn}, \mathrm{Cr}, \mathrm{Cu}, \mathrm{Cd}, \mathrm{Ni}, \mathrm{Pb}$, and As were performed using an inductively coupled plasma-atomic emission spectrometer (ICP-AES, Varian Vista Axial View; Mulgrave, Victoria, Australia), and $\mathrm{Hg}$ was measured using cold vapor atomic fluorescence spectroscopy (CV-AFS; Cetac M-8000, Omaha, NE). Analyses were performed according to standard methods (American Public Health Association 1998).

\section{Invertebrates}

Invertebrates were collected in the littoral substrates using a macrofauna net. Animals were sorted, washed with local water, and transported in polyethylene flasks to the laboratory. In the laboratory, organisms were chosen manually, counted, and identified live with available keys. Important macrofauna available in the sampling locations were collected: freshwater snails Pomacea haustrum and M. tuberculata (gastropods), shrimps Macrobrachium sp. and crabs Ucides sp. (Crustaceans, Decapoda), and water bugs belonging to the order Hemiptera. Information about their feeding habits is listed in Table 2. Samples were held overnight in water from the site for gut clearance. Individuals (numbers varied from 2 to 260, depending on the species abundance at each site) were pooled to prepare 1 sample for each species-location combination (thus avoiding pseudo replication), and the wet weight (ww) was recorded. In total, 16 samples were analyzed for Mãe-Bá Lagoon (Table 1), and 7 samples were analyzed for the surrounding areas. For gastropods, the soft tissues were dissected for analysis, whereas the whole body was taken for the other organisms. Organisms were stored frozen and then freeze dried (Labconco) at $-80^{\circ} \mathrm{C}$ until constant weight. Individual samples were ground in a marble mortar, and an aliquot of $0.5 \mathrm{~g} \mathrm{dw}$ was digested with $2 \mathrm{~mL}$ distilled deionized water and $5 \mathrm{~mL} \mathrm{HNO}_{3} 70.5 \%$ (Ultrex) in a microwave sample preparation system (MDS-2000 at $1920 \mathrm{~W}$; CEM) with 0 to $100 \%$ full power $(630 \mathrm{~W})$ capability adjustable in $1 \%$ increments. For a 12-position sample carousel, 5 sequential stages of varying power and time intervals were programmed: (1) $50 \%$ power, $30 \mathrm{PSI}$, 10 minutes; (2) $100 \%$ power, 70 PSI, 5 minutes; (3) $100 \%$ power, 100 PSI, 5 minutes; (4) $80 \%$ power, 125 PSI, 10 minutes; and (5) no power, no pressure, 15 minutes. Samples were then diluted to $20 \mathrm{~mL}$ with distilled deionized water for analyses. Total concentrations of $\mathrm{Fe}, \mathrm{Mn}$, $\mathrm{Zn}, \mathrm{Al}, \mathrm{Cu}, \mathrm{Cd}, \mathrm{Ni}, \mathrm{Pb}, \mathrm{Cr}$, and $\mathrm{As}$ were measured with inductively coupled-plasma mass spectrometry (ICP-MS; Thermo Finnigan Element 2; Bremen, Germany), and $\mathrm{Hg}$ was measured with CV-AFS (PS Analytic Millenium Merlin; Orpington, Kent, UK). 


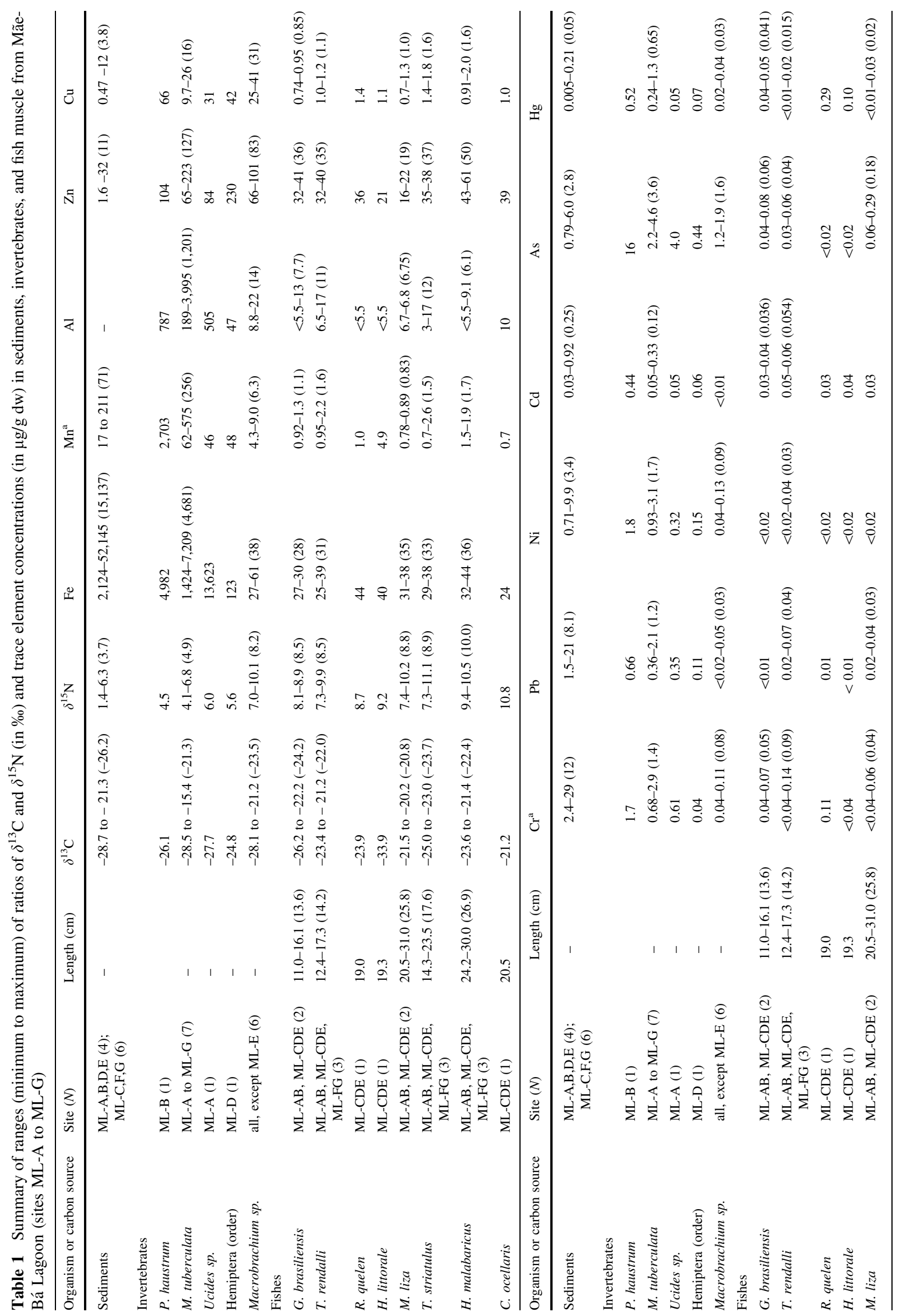


Fishes

To sample the main components of the fish community in the lagoons, samples were collected using gill nets of various mesh sizes $(20,25,30,40$, and $50 \mathrm{~mm})$. They were placed at the sites in the afternoon and removed the next morning. A total of 61 individuals, representing 3 orders and 8 species were collected: Perciforme (Geophagus brasiliensis, Tilapia rendalli, Mugil liza, and Cichla ocellaris), Siluriforme (Hoplosternum littorale, Trachelyopterus striatulus, and Rhamdia quelen), and Characiforme (Hoplias malabaricus) (Table 2). Fish were transported on ice to the laboratory and preserved frozen $\left(-20^{\circ} \mathrm{C}\right)$. They were defrosted, and individual weights $( \pm 0.1 \mathrm{~g})$ and lengths $( \pm 1 \mathrm{~mm})$ were measured. Whole fishes were dissected shortly after thawing. Muscles from all individuals, as well as gills and livers from fishes collected at site ML$\mathrm{CDE}$, were removed and weighed. The tissues were freeze dried at $-80^{\circ} \mathrm{C}$ until constant weight. Muscle, gill, and liver of the specimens of each species-location combination were pooled to avoid pseudo replication and homogenized. In total, for muscle tissue, 16 samples were analyzed for Mãe-Bá Lagoon (Table 1), and 3 samples were analyzed for the surrounding areas. For gill and liver tissue, 8 and 7 samples, respectively, were analyzed for Mãe-Bá Lagoon. Fish samples were ground in a marble mortar, and an aliquot of $0.5 \mathrm{~g} \mathrm{dw}$ was digested with $2 \mathrm{~mL}$ distilled deionized water and $5 \mathrm{~mL} \mathrm{HNO}_{3} 70.5 \%$ (Ultrex) in the microwave sample preparation system as previously described. Samples were then diluted to $20 \mathrm{~mL}$ with distilled deionized water for analyses. Total trace element concentrations were measured as previously described. To compare our values with those in the literature, we calculated trace element concentrations on a wet-weight basis by dividing the dry-weight results by the calculated conversion factor of lost humidity. Condition factors ([body weight $\left.\left.(\mathrm{g}) /(\text { length }(\mathrm{cm}))^{3}\right] \times 100\right)$ and liver somatic indexes ([liver weight $(\mathrm{g}) /$ body weight $(\mathrm{g})] \times 100$ ) were not significantly different among locations and therefore did not affect the results.

Stable Isotopes Analysis

To determine whether differences in trace element uptake of preys could explain the variability of concentrations in their predators, the relations between predator and prey and the different trophic levels were identified within Mãe-Bá Lagoon using stable isotopes and available dietary information. For interpretation of fish data, only muscle from the dorsal region was taken because its isotopic composition is expected to be less variable than the other parts of the body (Pinnegar 1999; Zuanon et al. 2006). 
Table 2 Invertebrates and fish species collected in the study area and their ecologic characteristics

\begin{tabular}{llll}
\hline Local name (popular name) & Scientific name & Feeding type (food items) & Biotic compartment \\
\hline Red-rim melania (snail) & M. tuberculatus & Detritivorous, herbivorous (organic debris) & Plants, benthos \\
Snail & P. haustrum & Herbivorous & Plants, benthos \\
Shrimp & Macrobrachium sp. & Omnivorous (detritus, algae, animal prey) & Benthos \\
Crab & Ucides sp. & Omnivorous (detritus, algae, animal prey) & Benthos \\
Water bug & Hemiptera (order) & Omnivorous (fluids of plants, insects, small animals) & Benthos \\
Acará (pearl cichlid) & G. brasiliensis & Omnivorous (debris, algae, invertebrates) & Benthopelagic \\
Tilápia & T. rendalli & Omnivorous (debris, algae, invertebrates) & Benthopelagic \\
Cambotá, Cascudo (catfish) & H. littorale & Omnivorous (debris, algae, invertebrates) & Demersal \\
Tainha (mullet) & M. liza & Omnivorous (debris, algae, invertebrates) & Demersal \\
Cumbaca, Duiá (singing catfish) & T. striatulus & Invertivorous (aquatic and terrestrial invertebrates) & Demersal \\
Bagre, Jundiá (freshwater catfish) & R. quelen & Carnivorous (fish: acaras and invertebrates) & Benthopelagic \\
Traíra & H. malabaricus & Carnivorous (fish: acaras, tilapias, and invertebrates) & Benthopelagic \\
Tucunaré & C. ocellaris & Carnivorous (fish: acaras and tilapias) & Benthopelagic \\
\hline
\end{tabular}

Oven-dried sediments and freeze-dried invertebrates and fish samples were homogenized, and subsamples were weighed in tin capsules on a microbalance (Sartorius M2P; Goettingen, Germany) for analyses of $\mathrm{N}(1.2 \pm 0.2 \mathrm{mg})$ and $\mathrm{C}(0.5 \pm 0.1 \mathrm{mg})$. Stable isotopes were measured in separate runs for $\mathrm{N}$ and $\mathrm{C}$ using an elemental analyzer (NC2500; ThermoQuest Italia, Rodana, Italy) coupled with an isotope ratio mass spectrometer (Delta Plus; ThermoQuest Finnigan, Bremen, Germany).

Stable isotope values were expressed as a ratio $(\mathrm{R})$ of the heavy to the light isotope $\left({ }^{13} \mathrm{C} /{ }^{12} \mathrm{C}\right.$ or $\left.{ }^{15} \mathrm{~N} /{ }^{14} \mathrm{~N}\right)$ and standardized with respect to internationally recognized reference materials (atmospheric air for N and VPDB [Vienna Pee Dee belemnite] for C) as follows (Equation 1):

$\delta(\%)=\left[\left(R_{\text {sample }} / R_{\text {reference }}\right)-1\right] \times 1000$.

The official standards used for $\delta^{13} \mathrm{C}$ were as follows: (1) United States Geological Survey-24 graphite (National Institute of Standards and Technology [NIST], Gaithersburg, MD; $\delta^{13} \mathrm{C}-16.05 \%$ ); (2) IAEA-601 benzoic acid (International Atomic Energy Agency, Vienna, Austria, $\delta^{13} \mathrm{C}-28.81 \%$ ); and (3) IAEA-CH7 PEF $\left(\delta^{13} \mathrm{C}-32.15 \%\right.$ ). The official standards used for $\delta^{15} \mathrm{~N}$ were IAEA-N1 $(0.43 \%)$ and IAEA-N2 $(20.41 \%$ ). An organic peat soil sample with a known value of $\delta^{13} \mathrm{C}-28.5 \%$ and $\delta^{15} \mathrm{~N}$ $-1.01 \%$ was used as quality control. Instrument precision was better than $0.15 \%$ for $\mathrm{C}$ and $\mathrm{N}$ based on replicate analysis of standard reference materials.

\section{Quality Control}

Analytic quality of the trace element determinations in sediments was monitored by comparison with the standard reference material 1944 (New York/New Jersey waterway sediment [NIST]). For invertebrates and fishes, quality control was assured by the certified reference material DOLT-2 (dogfish liver, National Research Council, Ottawa, Canada) and the standard reference material 2977 (mussel tissue [NIST]). Comparison of measured concentrations in the reference materials with the certified values showed agreement within $\pm 10 \%$ for most elements. The exceptions were $\mathrm{Hg}$ and $\mathrm{As}$ for invertebrates, $\mathrm{Hg}$ and $\mathrm{Ni}$ for fish, and $\mathrm{Cr}$ and $\mathrm{Ni}$ for sediments, for all of which the matching was within $\pm 20 \%$. Cr in fish and $\mathrm{Mn}$ in sediment showed a less favorable matching $( \pm 30 \%)$. For these metals, the results were accepted because of the satisfactory repeatability (coefficient of variation $<15 \%$ for $\mathrm{Cr}$ and $<5 \%$ for $\mathrm{Mn}$ ) and were used only for relative comparisons. The recovery for $\mathrm{Al}$ in sediment measurements was low $(30 \% \pm 3 \%)$. This was probably explained by its association with silicates, which were not decomposed in acid digestion with aqua regia. Therefore, we excluded $\mathrm{Al}$ from the data analysis for sediments.

During analysis, calibration and verification standards were regularly used in measurements series to evaluate the calibration curves. Blank verification samples were frequently run to verify absence of carryover effects. Standards and internal control samples were included in the final analysis to correct for drift of baseline and response factor during analysis. Analytic detection limits were based on three times the SDs of the reagent blanks measurements. Detection limit for sediments analysis was (in $\mu \mathrm{g} / \mathrm{g} \mathrm{dw}$ ) 60 for $\mathrm{Fe}, 0.24$ for $\mathrm{Mn}, 0.59$ for $\mathrm{Zn}, 0.43$ for $\mathrm{Cu}, 1.2$ for $\mathrm{Cr}$, 0.13 for $\mathrm{Pb}, 0.07$ for $\mathrm{Ni}, 0.01$ for $\mathrm{Cd}, 0.17$ for As, and 0.002 for $\mathrm{Hg}$. For invertebrates, detection limit was (in $\mu \mathrm{g} / \mathrm{g} \mathrm{dw}$ ) 0.90 for $\mathrm{Fe}, 0.10$ for $\mathrm{Mn}, 0.80$ for $\mathrm{Al}, 0.60$ for $\mathrm{Zn}, 0.06$ for $\mathrm{Cu}, 0.02$ for $\mathrm{Cr}, 0.02$ for $\mathrm{Pb}, 0.03$ for $\mathrm{Ni}, 0.01$ for $\mathrm{Cd}, 0.005$ for $\mathrm{As}$, and 0.004 for $\mathrm{Hg}$. In the case of fish analysis, detection limit was (in $\mu \mathrm{g} / \mathrm{g} \mathrm{dw}$ ) 0.40 for $\mathrm{Fe}, 0.01$ for $\mathrm{Mn}$, 5.5 for $\mathrm{Al}, 0.20$ for $\mathrm{Zn}, 0.10$ for $\mathrm{Cu}, 0.04$ for $\mathrm{Cr}, 0.01$ for 
$\mathrm{Pb}, 0.02$ for $\mathrm{Ni}, 0.005$ for $\mathrm{Cd}, 0.02$ for $\mathrm{As}$, and 0.01 for $\mathrm{Hg}$. The repeatability was further monitored by duplicate detections of each sample. All reagents used during analysis were of at least analytic grade.

\section{Statistical Analysis}

Statistical data analysis was performed using the software package SPSS for Windows (version 16.0; SPSS, Chicago, IL). One half of the value of the limit of detection of each trace element was substituted for those values below the limit of detection and applied in statistical analyses. The combinations of species and locations, built up by grouping various individuals per species, enabled us to decrease SDs and biases in estimates of the averages. Before statistical analysis, data were tested for normality using KolmogorovSmirnov test and for homogeneity of variance using Levene's test (Field 2005). Logarithmic transformations to correct for nonhomogeneous variance and nonnormality were applied when necessary. Independent sample $t$ tests, one-sample $t$ tests, and one-way analysis of variance (ANOVA) with Bonferroni post hoc tests were used to compare the concentrations of trace elements among compartments (sediments $N=10$, invertebrates $N=16$, and fishes $N=16$ ), among fish tissues (muscle $N=8$, liver $N=7$, and gill $N=8$ ), and among species (for example, gastropods $M$. tuberculata and $P$. haustrum $N=8$ and Macrobrachium sp. $N=6$ ). For those variables that did not show a normal distribution or a homogeneous variance, not even after transformation, nonparametric Kruskal-Wallis and Mann-Whitney tests (with Bonferroni correction) were applied. Simple linear regression analysis was employed to analyze relations between trace element concentrations and $\delta^{15} \mathrm{~N}$. Because of the different number of observations among species, regressions were performed with a weighted least squares model to assure that all species contributed equally to the regression analysis. A probability value $<0.05$ was considered to indicate statistical significance in this study.

\section{Results and Discussion}

Trace Element Accumulation in Sediments and Biota

The concentrations of trace elements in sediments, invertebrates, and fishes (muscle) from Mãe-Bá Lagoon are listed in Table 1. Concentrations of $\mathrm{Fe}, \mathrm{Cr}, \mathrm{Ni}, \mathrm{Pb}$, and $\mathrm{Cd}$ were significantly higher in sediments than in invertebrates and fishes (Mann-Whitney test, $p<0.05$ ). The concentrations of several elements-such as $\mathrm{Fe}, \mathrm{Mn}, \mathrm{Al}, \mathrm{Zn}, \mathrm{Cu}, \mathrm{Cr}$, $\mathrm{Ni}, \mathrm{Pb}$, and $\mathrm{As}$ - in invertebrates were significantly higher than in the fishes analyzed (Mann-Whitney test, $p<0.05$ ). Trace element levels in invertebrates varied widely among taxa and even within closely related taxa (Table 1). The gastropods $M$. tuberculata and $P$. haustrum generally had the highest element levels, whereas Macrobrachium sp. showed the lowest trace element content (independent sample $t$ test, $p<0.05$ ). Among the crustaceans, the crab Ucides sp. generally showed higher trace element levels compared with the shrimp Macrobrachium sp. (one-sample $t$ test, $p<0.05)$. However, in this study regarding $N=1$ for Ucides sp., data from Pereira et al. (2008) corroborate this finding. Possible explanations for intertaxon variability in element concentrations include species-specific differences in bioaccumulation dynamics as well as differences in trace element exposure, such as those related to dietary preferences, foraging behavior, food web structure, and trophic position (Croteau et al. 2005).

Trace element concentrations in fish muscle (except $\mathrm{Cd}$ ) showed no significant correlations with fish length, indicating that the results were not affected by potential differences in fish age. Relatively high concentrations of $\mathrm{Hg}$ were observed in $H$. malabaricus (average $1.0 \mu \mathrm{g} / \mathrm{g} \mathrm{dw}$ ) compared with other fish species ( $<0.01$ to $0.29 \mu \mathrm{g} / \mathrm{g} \mathrm{dw}$ ). Concentrations of toxic elements, such as $\mathrm{Cd}, \mathrm{Pb}, \mathrm{As}, \mathrm{Ni}$, and $\mathrm{Cr}$, were low in fish muscle $(<0.5 \mu \mathrm{g} / \mathrm{g} \mathrm{dw})$. Comparing fish tissues across all species, liver showed the highest tissue concentrations of the essential metals $\mathrm{Fe}$ and $\mathrm{Cu}$, whereas $\mathrm{Zn}$ was significantly higher in liver and gill (Table 3) (one-way ANOVA $p<0.05$ for $\mathrm{Fe}$ and $\mathrm{Zn}$ and Mann-Whitney test $p<0.05$ for $\mathrm{Cu}$ ). The trace metals $\mathrm{Hg}$ and $\mathrm{Cd}$ were high not only in liver but also in muscle, whereas $\mathrm{Mn}$ and $\mathrm{Cr}$ were significantly higher in gill compared with muscle (one-way ANOVA $p<0.05$ ). Higher trace element levels in fish tissues were generally found in the species $H$. littorale, $R$. quelen, $H$. malabaricus, and C. ocellaris (Tables 1 and 3). Despite the fact that the species $R$. quelen, H. malabaricus and $C$. ocellaris have piscivourous habits, they may also feed on benthic invertebrates and sediments, preferring the muddy bottom of shallow waters (Menezes and Figueiredo 1980). High trace element concentrations usually occur in fish associated with substrata or in fish that feed on it.

\section{Relations Between $\delta^{13} \mathrm{C}$ and $\delta^{15} \mathrm{~N}$ Values}

Stable carbon isotope values varied greatly among food web components at Mãe-Bá Lagoon (-33.9\%o to $-15.4 \%$ ), suggesting assimilation of carbon from a variety of sources (Table 1 and Fig. 2). The sediments, sampled to estimate the source of organic matter, were lighter in $\delta^{13} \mathrm{C}$ $(-26.2 \%$ o $\pm 2.3 \%$ ) compared with invertebrates and fishes $(-23.2 \%$ o $\pm 3.4 \%$ ) (one-way ANOVA, $p<0.05)$. Among 
Table 3 Trace element concentrations ( $\mu \mathrm{g} / \mathrm{g} \mathrm{dw}$ ) in gills and liver from fishes collected at Mãe-Bá Lagoon (region ML-CDE)

\begin{tabular}{|c|c|c|c|c|c|c|c|c|c|c|c|c|}
\hline Species & Tissue & $\mathrm{Fe}$ & $\mathrm{Mn}$ & $\mathrm{Al}$ & $\mathrm{Zn}$ & $\mathrm{Cu}$ & $\mathrm{Cr}^{\mathrm{a}}$ & $\mathrm{Pb}$ & $\mathrm{Ni}$ & $\mathrm{Cd}$ & $\mathrm{Hg}$ & As \\
\hline \multirow[t]{2}{*}{ G. brasiliensis } & Liver & 867 & 20 & 335 & 58 & 15 & 0.37 & 0.27 & 0.16 & 0.15 & 0.09 & 0.25 \\
\hline & Gill & 234 & 11 & $<5.5$ & 124 & 1.5 & 0.13 & 0.03 & $<0.02$ & 0.01 & $<0.01$ & 0.10 \\
\hline \multirow[t]{2}{*}{ T. rendalli } & Liver & 280 & 7.5 & 14 & 141 & 15 & 0.20 & 0.09 & 0.06 & 0.07 & 0.09 & 0.08 \\
\hline & Gill & 289 & 7.0 & 13 & 93 & 2.7 & 0.33 & 0.06 & 0.04 & 0.01 & $<0.01$ & 0.04 \\
\hline \multirow[t]{2}{*}{ R. quelen } & Liver & 1,121 & 4.8 & $<5.5$ & 96 & 17 & 0.05 & $<0.01$ & $<0.02$ & 0.14 & 0.28 & 0.08 \\
\hline & Gill & 154 & 28 & $<5.5$ & 85 & 1.9 & 0.32 & 0.04 & $<0.02$ & $<0.005$ & 0.05 & 0.03 \\
\hline \multirow[t]{2}{*}{ H. littorale } & Liver & 2,310 & 3.8 & $<5.5$ & 110 & 150 & 0.10 & 0.02 & 0.03 & 0.03 & 0.02 & 0.04 \\
\hline & Gill & 214 & 23 & $<5.5$ & 59 & 7.6 & 0.05 & 0.02 & $<0.02$ & $<0.005$ & $<0.01$ & $<0.02$ \\
\hline M. liza & Gill & 268 & 57 & 24 & 94 & 2.7 & 0.11 & 0.36 & 0.03 & 0.02 & $<0.01$ & 0.12 \\
\hline \multirow[t]{2}{*}{ T. striatulus } & Liver & 567 & 3.9 & $<5.5$ & 92 & 10 & 0.17 & 0.02 & $<0.02$ & 0.08 & 0.07 & 0.07 \\
\hline & Gill & 186 & 13 & $<5.5$ & 113 & 3.2 & 0.39 & 0.03 & 0.04 & 0.01 & 0.02 & 0.08 \\
\hline \multirow[t]{2}{*}{ H. malabaricus } & Liver & 1,835 & 5.0 & $<5.5$ & 305 & 195 & $<0.04$ & 0.08 & $<0.02$ & 0.08 & 0.09 & $<0.02$ \\
\hline & Gill & 118 & 31 & 6.6 & 356 & 1.9 & 0.60 & 0.03 & 0.07 & 0.03 & $<0.01$ & 0.03 \\
\hline \multirow[t]{2}{*}{ C. ocellaris } & Liver & 610 & 19 & $<5.5$ & 201 & 51 & 0.06 & $<0.01$ & 0.04 & 0.05 & 0.24 & 0.04 \\
\hline & Gill & 86 & 24 & $<5.5$ & 124 & 1.2 & 0.39 & $<0.01$ & $<0.02$ & 0.01 & $<0.01$ & $<0.02$ \\
\hline
\end{tabular}

${ }^{a}$ The methods applied for $\mathrm{Cr}$ have limited reliability

Fig. 2 Mean $\pm \mathrm{SD} \delta^{13} \mathrm{C}$ and invertebrates, and fishes from Mãe-Bá Lagoon $\delta^{15} \mathrm{~N}$ of sediments,

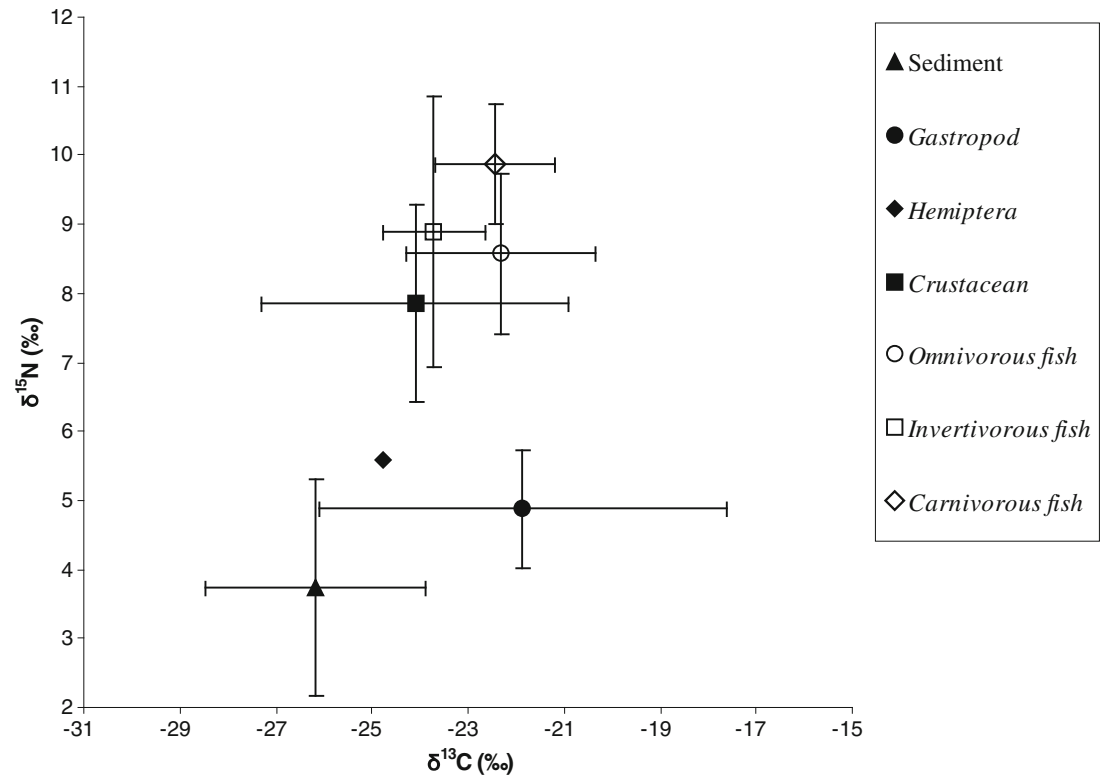

the fish species, the $\delta^{13} \mathrm{C}$ value for $H$. littorale strongly deviated $(-33.9 \%)$ from that of the other species $(-22.6 \%$ $\pm 1.6 \%$ ) (Table 1). Because H. littoralle feeds on different carbon sources, this species probably belongs to a different food chain and therefore was excluded from analysis of trace element trophic transfer. Based on isotopic values for primary producers reported in the literature for Brazilian freshwater ecosystems, we infer that most fish species from Mãe-Bá Lagoon are probably benthic consumers, receiving significant part of their energy from sources such as algae $\left(\delta^{13} \mathrm{C}\right.$ between $-19 \%$ and $-25 \%$ ) (Brito et al. 2006) and macrophytes $\left(\delta^{13} \mathrm{C}\right.$ between $-25.5 \%$ and -27\%o) (Garcia et al. 2006).
Stable nitrogen isotope data (ranging from $1.4 \%$ to 11.1\%, Table 1 and Fig. 2), were used to indicate trophic positions of organisms in the food web of Mãe-Bá Lagoon. The value of $\delta^{15} \mathrm{~N}$ for sediments was $3.7 \%$ o $\pm 1.6 \%$. Among the invertebrates, the gastropods $P$. haustrum and $M$. tuberculata and the insect Hemiptera occupied the lower position in the food web $\left(\delta^{15} \mathrm{~N} 5.0 \%\right.$ o $\pm 0.8 \%$ ). The next level was composed by the crustaceans Macrobrachium sp. and Ucides sp., the omnivorous fishes G. brasiliensis, $T$. rendalli, and $M$. liza, and the invertivorous fish T. striatulus $\left(\delta^{15} \mathrm{~N} 8.3 \% \pm \pm 1.4 \%\right)$. The carnivorous species $R$. quelen, $H$. malabaricus, and $C$. ocellaris occupied higher trophic position $\left(\delta^{15} \mathrm{~N} 9.9 \% \mathrm{o} \pm 0.9 \%\right.$ ). 


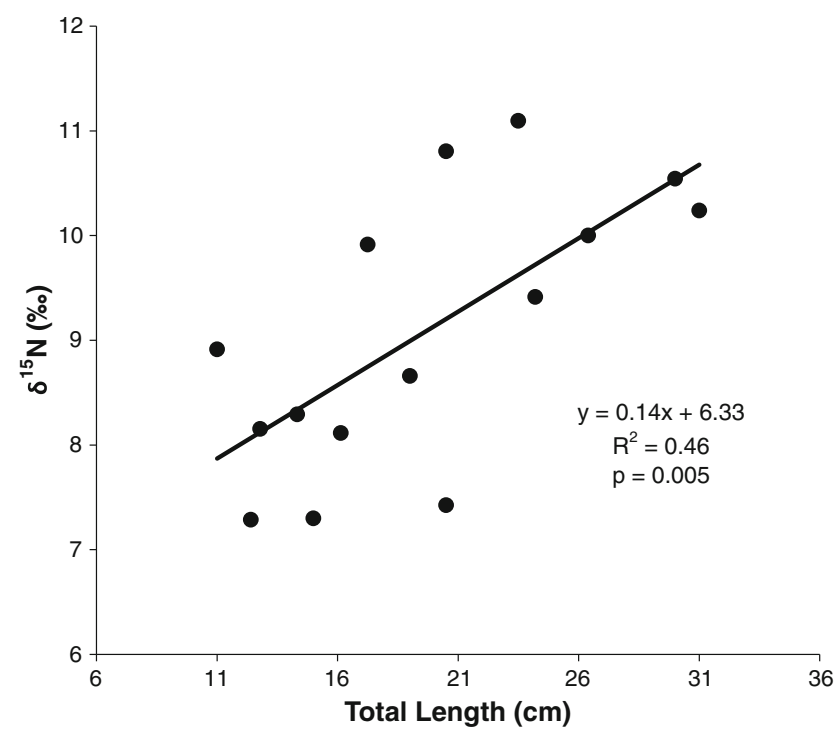

Fig. 3 Relation between $\delta^{15} \mathrm{~N}(\%)$ and total length (cm) of fishes $(N=15)$ from Mãe-Bá Lagoon

Fish body size significantly increased with trophic level (as indicated by $\delta^{15} \mathrm{~N}$ ) (Fig. 3). The differences in $\delta^{15} \mathrm{~N}$ values among different length classes probably reflect changes in feeding behaviour of larger individuals compared with smaller ones. Moreover, they also suggest that age is an important factor controlling the trophic position of fishes in the food web.

\section{Relations Between Trace Element Content and $\delta^{15} \mathrm{~N}$ Values}

Relations between the $\delta^{15} \mathrm{~N}$ and the log-transformed concentrations of trace elements in biota were examined to investigate the trophic level-dependent accumulation of trace elements in the organisms from Mãe-Bá Lagoon (Fig. 4). Concentrations of all trace elements, except $\mathrm{Hg}$, decreased with increasing $\delta^{15} \mathrm{~N}$ values because significant $(p<0.05)$ negative slopes were obtained for all elements analyzed (Table 4). Previous studies have shown negative correlations between $\delta^{15} \mathrm{~N}$ and various trace elements in different food webs (Campbell et al. 2005; Asante et al. 2008; Marin-Guirao et al. 2008), suggesting that some elements might be partially biodiluted with increased trophic level or might be bioconcentrated by organisms, but they do not biomagnify in food chains.

Because of comparisons between invertebrates and fishes can be biased due to biologic differences among species (Reinfelder et al. 1998), linear regressions were also performed separately for invertebrates and fishes at Mãe-Bá Lagoon (Table 4). As indicated by the significant $\mathrm{p}$ values, $\delta^{15} \mathrm{~N}$ values were negatively correlated with trace elements in invertebrates (except for $\mathrm{Cu}, \mathrm{Zn}$, and $\mathrm{As}$ ). However, except for Mn, no correlation between $\delta^{15} \mathrm{~N}$ and trace elements was observed in fishes $(p>0.05)$. Even with respect to $\mathrm{Hg}$, a trace metal that usually biomagnifies in higher-trophic animals, no significant positive correlations with $\delta^{15} \mathrm{~N}$ were observed in this study. This lack of clear trend may be due to the fast growth of fish species in the tropical areas, which could result in growth biodilution, as observed by Desta et al. (2007) in African catfish and by Ikemoto et al. (2008) in different species from Southeast Asia.

Decreasing concentrations of trace elements with trophic levels in invertebrates may be explained by species differences. The higher levels recorded in the gastropods $M$. tuberculata and $P$. haustrum compared with the crustacean Macrobrachium sp. reinforced the negative regressions observed. Gastropods are good trace element accumulators, which can probably be explained by their feeding habits of taking in sediment-bound and organic matter-adsorbed metals (Adewunmi et al. 1996; Eisemann et al. 1997; Lau et al. 1998; Callil and Junk 2001). Moreover, trace element assimilation efficiency in gastropods is high due to the binding of trace elements in available form, such as metallothioneins, or in less available forms, such as mineralized phosphate granules (Wang 2002). Although the diet of the crustacean decapods is based on detritus, it also includes several other items, such as insects, fish remains, small crustaceans, mollusks, and Polychaeta (Albertoni et al. 2003). These prey and food items probably show poor trace element assimilation, therefore limiting trophic transfer to their predators. Moreover, as suggested by Watanabe et al. (2008), invertebrates at higher trophic levels may exhibit increasingly efficient excretion of certain elements. With respect to some essential metals, such as $\mathrm{Cu}$ and $\mathrm{Zn}$, decapod crustaceans have developed mechanisms to regulate their body concentrations, showing constant total body concentrations independently of external environmental concentrations (Marsden and Rainbow 2004).

In the case of fish species, the general absence of significant relations between trace elements and $\delta^{15} \mathrm{~N}$, as well as the lack of clear patterns given by the signs of the slopes of the regression equations (Table 4), reflect the influence of omnivory on the species studied (Jardine et al. 2006). This means that the individuals collected, mostly juveniles, feed on more than one trophic level, despite being progressively enriched in $\delta^{15} \mathrm{~N}$ with age (as given by length). Moreover, there is less variation on assimilation patterns of trace elements among fish species than among invertebrates (Wang 2002). Furthermore, most trace elements accumulate in certain organs, such as liver and kidney, but are regulated to very low levels in fish muscle (Reinfelder et al. 1998). Even when using whole fish tissue for analysis, the same pattern is observed because muscle contributes to the most mass to the body of a fish. 
Fig. 4 Relations between trace element content (logtransformed $\mu \mathrm{g} / \mathrm{g} \mathrm{dw}$ ) and $\delta^{15} \mathrm{~N}$ values $(\% 0)$ in invertebrates and fishes $(N=31)$ from Mãe-Bá Lagoon. Lines represent the estimated linear relation between both variables. Linearregression equations and levels of significance are listed in Table 4

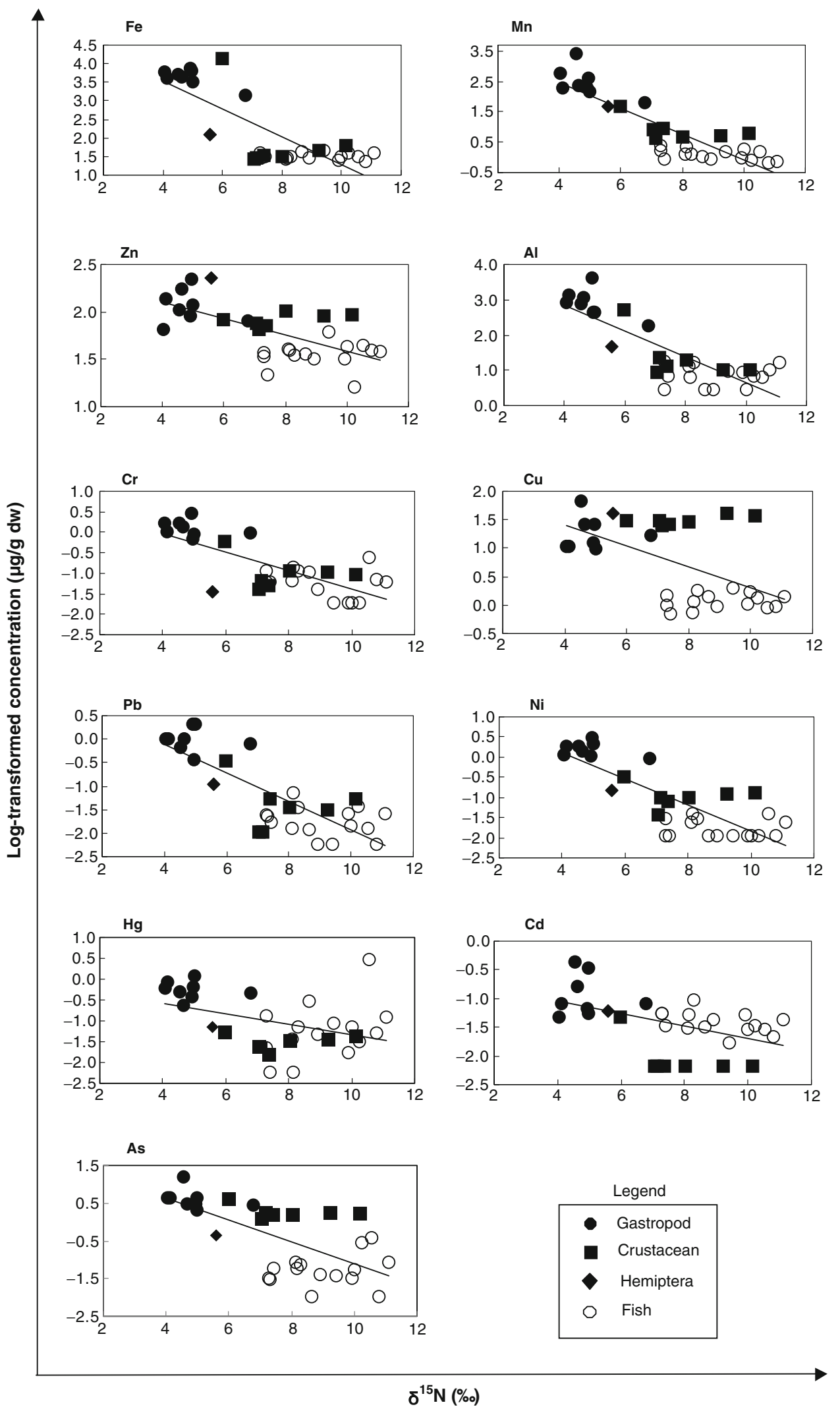

Several explanations may be possible for the observed lack of trophic transfer of trace elements among the study organisms. Some of the elements are actively regulated (e.g., $\mathrm{Cu}$ and $\mathrm{Zn}$ ) (Van Hattum et al. 1991), excreted, or detoxified and deposited as inert storage molecules (e.g., phosphate granules) and thus made unavailable for trophic 
Table 4 Linear-regression equations between log-transformed concentrations of trace elements and $\delta^{15} \mathrm{~N}$ for invertebrates (five species) and fishes (seven species) from Mãe-Bá Lagoon

\begin{tabular}{|c|c|c|c|c|c|c|c|c|c|c|c|c|}
\hline \multirow[t]{2}{*}{ Elements } & \multicolumn{4}{|c|}{ Invertebrates and fishes $(N=31)$} & \multicolumn{4}{|c|}{ Invertebrates $(N=16)$} & \multicolumn{4}{|c|}{ Fishes $(N=15)$} \\
\hline & Slope & Intercept & $R^{2}$ & $p$ & Slope & Intercept & $R^{2}$ & $p$ & Slope & Intercept & $R^{2}$ & $p$ \\
\hline $\mathrm{LogFe}$ & -0.362 & 4.955 & 0.589 & $<0.001$ & -0.439 & 5.582 & 0.380 & 0.011 & -0.014 & 1.636 & 0.037 & 0.490 \\
\hline $\log M n$ & -0.463 & 4.456 & 0.764 & $<0.001$ & -0.514 & 4.976 & 0.676 & $<0.001$ & -0.073 & 0.716 & 0.298 & $\mathbf{0 . 0 3 5}$ \\
\hline $\log Z n$ & -0.099 & 2.524 & 0.490 & $<0.001$ & -0.036 & 2.266 & 0.077 & 0.298 & 0.011 & 1.434 & 0.012 & 0.692 \\
\hline $\log \mathrm{Al}$ & -0.331 & 3.993 & 0.619 & $<0.001$ & -0.408 & 4.640 & 0.593 & $<0.001$ & 0.041 & 0.447 & 0.032 & 0.523 \\
\hline $\log C r$ & -0.193 & 0.584 & 0.441 & $<0.001$ & -0.257 & 1.000 & 0.285 & 0.033 & -0.065 & -0.620 & 0.070 & 0.342 \\
\hline $\log \mathrm{Cu}$ & -0.265 & 2.725 & 0.567 & $<0.001$ & -0.006 & 1.554 & 0.001 & 0.887 & 0.012 & -0.052 & 0.014 & 0.672 \\
\hline $\log \mathrm{Pb}$ & -0.292 & 0.943 & 0.681 & $<0.001$ & -0.307 & 1.159 & 0.525 & 0.002 & -0.075 & -1.140 & 0.092 & 0.271 \\
\hline $\operatorname{LogNi}$ & -0.317 & 1.242 & 0.694 & $<0.001$ & -0.272 & 1.198 & 0.505 & 0.002 & -0.025 & -1.584 & 0.025 & 0.577 \\
\hline $\mathrm{LogHg}$ & -0.080 & -0.461 & 0.078 & 0.128 & -0.277 & 0.720 & 0.519 & 0.002 & 0.150 & -2.591 & 0.094 & 0.267 \\
\hline $\log C d$ & -0.122 & -0.407 & 0.370 & $<0.001$ & -0.350 & 0.823 & 0.692 & $<0.001$ & -0.064 & -0.865 & 0.228 & 0.072 \\
\hline LogAs & -0.358 & 2.152 & 0.537 & $<0.001$ & -0.139 & 1.251 & 0.147 & 0.143 & 0.015 & -1.533 & 0.002 & 0.888 \\
\hline
\end{tabular}

The values listed in bold are significant at $p<0.05$

$N$ number of samples

Table $5 \delta^{13} \mathrm{C}$ and $\delta^{15} \mathrm{~N}$ (in \%o) and trace element concentrations (in $\mu \mathrm{g} / \mathrm{g} \mathrm{dw}$ ) in sediments, invertebrates, and fish muscle collected at SD, ND, GL, and IL

\begin{tabular}{|c|c|c|c|c|c|c|c|c|c|c|c|c|c|c|}
\hline Site & Species & $\delta^{13} \mathrm{C}$ & $\delta^{15} \mathrm{~N}$ & $\mathrm{Fe}$ & $\mathrm{Mn}^{\mathrm{a}}$ & $\mathrm{Al}$ & $\mathrm{Zn}$ & $\mathrm{Cu}$ & $\mathrm{Cr}^{\mathrm{a}}$ & $\mathrm{Pb}$ & $\mathrm{Ni}$ & $\mathrm{Cd}$ & As & $\mathrm{Hg}$ \\
\hline \multicolumn{15}{|c|}{ Sediments } \\
\hline ND & - & -31.2 & 7.6 & 62 & 243 & - & 112 & 154 & 51 & 27 & 14 & 1.17 & 16 & 0.37 \\
\hline GL & - & -27.1 & 6.2 & 20 & 39 & - & 14 & 2.3 & 32 & 20 & 8.0 & 0.30 & 5.7 & 0.08 \\
\hline $\mathrm{IL}$ & - & -24.5 & 5.4 & 7.1 & 55 & - & 6.9 & 1.9 & 11 & 9.6 & 1.1 & 0.11 & 9.2 & 0.03 \\
\hline \multicolumn{15}{|c|}{ Invertebrates } \\
\hline \multirow[t]{2}{*}{ ND } & P. haustrum & -37.9 & 10.4 & 1,969 & 1,354 & 928 & 378 & 228 & 4.7 & 1.7 & 3.2 & 0.59 & 14 & 0.51 \\
\hline & Hemiptera (order) & -43.1 & 11.5 & 303 & 33 & 153 & 207 & 35 & 0.49 & 0.27 & 0.37 & 0.04 & 0.78 & 0.08 \\
\hline \multirow[t]{3}{*}{ GL } & P. haustrum & -23.8 & 5.9 & 5,306 & 7,363 & 2,141 & 269 & 96 & 4.5 & 1.6 & 2.4 & 0.39 & 8.0 & 0.52 \\
\hline & M. tuberculata & -23.5 & 7.3 & 11,912 & 312 & 2,327 & 106 & 36 & 2.5 & 1.1 & 1.6 & 0.30 & 4.1 & 0.57 \\
\hline & Macrobrachium sp. & -23.7 & 11.8 & 29 & 2.8 & 34 & 85 & 22 & 0.05 & 0.02 & 0.03 & $<0.01$ & 0.60 & 0.04 \\
\hline \multirow[t]{2}{*}{ IL } & Macrobrachium sp. & -25.2 & 10.4 & 55 & 9.0 & 23 & 71 & 44 & 0.03 & $<0.02$ & 0.05 & 0.01 & 1.6 & 0.17 \\
\hline & Ucides sp. & -25.2 & 8.5 & 1,119 & 34 & 979 & 114 & 28 & 0.67 & 0.31 & 0.27 & 0.14 & 0.62 & 0.35 \\
\hline \multicolumn{15}{|l|}{ Fishes } \\
\hline SD & G. brasiliensis & -21.8 & 6.5 & 103 & 8.6 & 30 & 29 & 1.1 & 0.15 & 0.03 & 0.03 & 0.02 & 0.06 & 2.5 \\
\hline GL & H. littorale & -23.9 & 11.5 & 90 & 1.2 & 115 & 22 & 1.7 & 0.33 & 0.05 & 0.04 & 0.04 & 0.10 & 0.37 \\
\hline IL & G. brasiliensis & -26.0 & 7.7 & 142 & 3.8 & 126 & 68 & 1.3 & 0.17 & 0.17 & 0.09 & 0.12 & 0.23 & 0.08 \\
\hline
\end{tabular}

a The methods applied for $\mathrm{Mn}$ in sediments and $\mathrm{Cr}$ in fishes have limited reliability

transfer. In addition, some elements are poorly absorbed from the diet (Friberg et al. 1979) or are absorbed from other routes of exposure, such as adsorption over the gills and uptake by way of ingested water.

Comparison of Trace Element Concentrations With Those From Other Locations and With Guidelines for Human Consumption

To assess if anthropogenic inputs affect stable isotopes signatures and trace element levels at Mãe-Bá Lagoon, data were compared with concentrations from the mining area (sites SD and ND) and from two nearby lagoons (sites GL and IL, which do not receive industrial effluents). The $\delta^{13} \mathrm{C}$ values in sediments $(-31.2 \%$ ) and invertebrates $(P$. haustrum $-37.9 \%$ and Hemiptera, $-43.1 \%$ ) (Table 5) found at ND were lighter than their counterparts from Mãe-Bá Lagoon (sediments $-26.2 \% \pm 2.3 \%$, invertebrates P. haustrum $-26.1 \%$, and Hemiptera $-24.8 \%$ ) (Table 1). In contrast, $\delta^{15} \mathrm{~N}$ values in sediments $(7.6 \%)$ and invertebrates (P. haustrum 10.4\% and Hemiptera 11.5\%o) (Table 5) at ND were heavier than their counterparts from 
Mãe-Bá Lagoon (sediments 3.7\%o $\pm 1.6 \%$, invertebrates P. haustrum 4.5\%o, and Hemiptera $5.6 \%$ ) (Table 1). It is likely that the primary consumers at ND are receiving an allochthonous carbon source and are greatly influenced by higher nitrogen inputs due to industrial effluents, which contain amines used in the flotation process. Generally, trace element concentrations in sediments and invertebrates from ND were significantly higher compared with Mãe-Bá Lagoon (one-sample $t$ test, $p<0.05$ ). Moreover, levels of $\mathrm{Fe}, \mathrm{Mn}$, and $\mathrm{Hg}$ were significantly higher in fish collected at SD compared with its counterpart from MãeBá Lagoon (one-sample $t$ test, $p<0.05$ ). These results indicate that the iron ore mining and processing activities constitute potential sources of trace elements to the lagoon. However, because bioavailability was predicted to be low (Pereira et al. 2008), trace element contamination of the local biota seems to be limited at Mãe-Bá Lagoon.

Trace element levels, except for $\mathrm{Cd}$, $\mathrm{As}$, and $\mathrm{Hg}$, in $P$. haustrum from GL were higher than levels found at Mãe-Bá Lagoon. Moreover, trace element concentrations in fish muscle from GL and IL were generally significantly higher than levels recorded in the same species from MãeBá Lagoon (one-sample $t$ test, $p<0.05$ ) (Table 5). These results confirm the occurrence of anthropogenic inputs (probably by atmospheric deposition) and the predicted high trace element bioavailability in these lagoons (Pereira et al. 2008).

Except for $\mathrm{Fe}, \mathrm{Mn}, \mathrm{Al}$, and $\mathrm{Hg}$, concentrations of trace elements in invertebrates collected at Mãe-Bá Lagoon were lower than levels found for other species from contaminated areas elsewhere (Carvalho et al. 1991; Silva et al. 2001; Amado-Filho et al. 2008). Levels of Fe (27 to $13,623 \mu \mathrm{g} / \mathrm{g} \mathrm{dw}$ ), Mn (4 to 2,703 $\mu \mathrm{g} / \mathrm{g} \mathrm{dw}$ ), and Al (9 to $3,995 \mu \mathrm{g} / \mathrm{g} \mathrm{dw}$ ) are probably related to the presence of these elements in the local sediments, which are rich in iron oxides released by the mining operations. The concentrations of $\mathrm{Hg}$ in gastropods ( 0.24 to $1.3 \mu \mathrm{g} / \mathrm{g} \mathrm{dw})$ from Mãe-Bá Lagoon are consistent with the data of Lacerda et al. (1991) and Callil and Junk (2001), who observed similar $\mathrm{Hg}$ levels in gastropods in areas where this metal was used in the gold-extraction process. Although these species are not in the diet of the local human population, their contamination can represent a potential risk to the local ecosystem because of their importance for local food webs.

Levels of $\mathrm{Fe}$ (280 to $2,310 \mu \mathrm{g} / \mathrm{g} \mathrm{dw}$ ) and $\mathrm{Cu}$ (10 to $195 \mu \mathrm{g} / \mathrm{g} \mathrm{dw}$ ) in fish livers from Mãe-Bá Lagoon are comparable with those of other species from freshwater systems considered to be polluted by trace metals (Swales et al. 1998; Avenant-Oldewage and Marx 2000; Lwanga et al. 2003; Wagner and Boman 2003; Yilmaz et al. 2007).
However, concentrations of all trace elements in fish muscle were low and did not exceed the maximum levels for consumption established by Brazilian legislation (Brasil 1965, 1998). Levels were also lower than permissible limits reported by the Food and Agriculture Organization of the United Nations (FAO; Nauen 1983), the United States Environmental Protection Agency (USEPA 1989), and the European Union (2001). Based on the maximum acceptable weekly intake quantity of trace elements as defined by the USEPA (1998) and the FAO/World Health Organization (2007), we conclude that fish muscle of all species studied from Mãe-Bá Lagoon is suitable for human consumption. People must eat, on average, $>20 \mathrm{~kg}$ fish/ week to exceed the recommended safety limits for trace element intake.

\section{Conclusion}

This study has shown that trace element accumulation in biota from a tropical coastal lagoon depends not only on the trophic position of the organisms but also on the characteristics of the species involved. Gastropods, which occupy lower trophic positions, generally show higher trace element levels than crustaceans and fishes, probably explained by their feeding habit based on detritus and their high metabolic capacity of trace elements. Although age (based on length) covaries with the trophic position of fishes, it does not influence the concentration of trace elements. Omnivory, low variation in trace element assimilation, and fast growth may explain the general lack of correlation between $\delta^{15} \mathrm{~N}$ and trace element levels in fishes. Trace element accumulation is variable among fish tissues, with higher levels of most trace elements in liver compared with muscle and gill. Trace element concentrations in fish muscle are lower than international safety baseline standards for human consumption. Organisms from other contaminated sites, including the stations directly influenced by the iron ore mining and processing waste and from two nearby coastal lagoons, are generally exposed to higher levels of trace elements than those from the studied lagoon.

Acknowledgments We thank O. J. Epema from the Centre for Water Management (Rijkswaterstaat, The Netherlands) for trace element analyses. We also thank A. R. Gobo from Laboratório de Ciências Ambientais for fieldwork support and preparation of samples. This research was supported by CAPES (Ministry of Education, Brazil) and Samarco Mineração S/A.

Open Access This article is distributed under the terms of the Creative Commons Attribution Noncommercial License which permits any noncommercial use, distribution, and reproduction in any medium, provided the original author(s) and source are credited. 


\section{References}

Adewunmi CO, Becker W, Kuehnast O, Oluwole F, Dorfler G (1996) Accumulation of copper, lead, and cadmium in freshwater snails in southwestern Nigeria. Sci Total Environ 193:69-73

Albertoni EF, Palma-Silva C, Esteves FA (2003) Overlap of dietary niche and electivity of three shrimp species (Crustacea, Decapoda) in a tropical coastal lagoon (Rio de Janeiro, Brazil). Rev Bras Zool 20:135-140

Alongi DM (1998) Coastal ecosystem processes. CRC Press, Boca Raton, FL

Amado-Filho GM, Salgado LT, Rebelo MF, Rezende CE, Karez CS, Pfeiffer WC (2008) Heavy metals in benthic organisms from Todos os Santos Bay, Brazil. Braz J Biol 68:95-100

American Public Health Association (1998) Standard methods for the examination of water and wastewater. APHA, Washington, DC

Asante KA, Agusa T, Mochizuki H, Ramu K, Inoue S, Kubodera T et al (2008) Trace elements and stable isotopes (delta C-13 and delta N-15) in shallow and deep-water organisms from the East China Sea. Environ Pollut 156:862-873

Avenant-Oldewage A, Marx HM (2000) Bioaccumulation of chromium, copper and iron in the organs and tissues of Clarias gariepinus in the Olifants River, Kruger National Park. Water Safe 26:569-582

Barnes RSK (1980) Coastal lagoons: the natural history of a neglected habitat. Cambridge University Press, Cambridge, England

Brasil (1965) Decreto $N^{\circ}$ 55.871, de 26 de março de 1965. Diário Oficial da União, Brasília, DF

Brasil (1998) Portaria $\mathrm{N}^{\circ} 685$, de 27 de agosto de 1998. Diário Oficial da União, Brasília, DF

Brito EF, Moulton TP, De Souza ML, Bunn SE (2006) Stable isotope analysis indicates microalgae as the predominant food source of fauna in a coastal forest stream, south-east Brazil. Austral Ecol 31:623-633

Callil CT, Junk WJ (2001) Aquatic gastropods as mercury indicators in the Pantanal of Pocone region (Mato Grosso, Brasil). Water Air Soil Pollut 125:319-330

Campbell LM, Norstrom RJ, Hobson KA, Muir DCG, Backus S, Fisk AT (2005) Mercury and other trace elements in a pelagic Arctic marine food web (Northwater Polynya, Baffin Bay). Sci Total Environ 351-352:247-263

Carvalho CEV, Lacerda LD, Gomes MP (1991) Heavy metal contamination of the marine biota along the Rio de Janeiro coast, SE-Brazil. Water Air Soil Pollut 57-58:645-653

Croteau MN, Luoma SN, Stewart AR (2005) Trophic transfer of metals along freshwater food webs: evidence of cadmium biomagnification in nature. Limnol Oceanogr 50:1511-1519

Desta Z, Borgstrom R, Rosseland BO, Dadebo E (2007) Lower than expected mercury concentration in piscivorous African sharptooth catfish Clarias gariepinus (Burchell). Sci Total Environ 376:134-142

European Union (2001) Comission regulation No. 466/2001 of 8 March 2001. Official Journal of European Communities 1.77/1

Eisemann JD, Beyer WN, Bennetts RE, Morton A (1997) Mercury residues in south Florida apple snails (Pomacea paludosa). Bull Environ Contam Toxicol 58:739-743

FAO/WHO (2007) Summary of evaluations performed by the Joint FAO/WHO Expert Committee on Food Additives (JECFA 19562007). Available at: http://jecfa.ilsi.org/. Accessed 20 Sept 2009

Field AP (2005) Discovering statistics using SPSS. Sage, London, England

France RL (1995) Differentiation between littoral and pelagic food webs in lakes using stable carbon isotopes. Limnol Oceanogr 40:1310-1313
Friberg L, Norberg GF, Vouk VB (1979) Handbook of metal toxicology. Elsevier/North Holland, Amsterdam, The Netherlands

Garcia AM, Hoeinghaus DJ, Vieira JP, Winemiller KO, Marques DMLM, Bemvenuti MA (2006) Preliminary examination of food web structure of Nicola Lake (Taim Hydrological System, south Brazil) using dual $\mathrm{C}$ and $\mathrm{N}$ stable isotope analyses. Neotrop Ichthyol 4:279-284

Ikemoto T, Tu NPC, Okuda N, Iwata A, Omori K, Tanabe S et al (2008) Biomagnification of trace elements in the aquatic food web in the Mekong Delta, South Vietnam, using stable carbon and nitrogen isotope analysis. Arch Environ Contam Toxicol 54:504-515

Jardine TD, Kidd KA, Fisk AT (2006) Applications, considerations, and sources of uncertainty when using stable isotope analysis in ecotoxicology. Environ Sci Technol 40:7501-7511

Kjerfve B, Magill KE (1989) Geographic and hydrodynamic characteristics of shallow coastal lagoons. Mar Geol 88:187-199

Kjerfve B (1994) Coastal lagoon. In: Kjerfve B (ed) Coastal lagoon processes. Elsevier Science BV, Amsterdam, The Netherlands, pp 1-8

Knoppers BA (1994) Aquatic primary production in coastal lagoons. In: Kjerfve B (ed) Coastal lagoon processes. Elsevier Science BV, Amsterdam, The Netherlands, pp 243-286

Lacerda LD, Pfeiffer WC, Marins RV, Rodrigues S, Souza CMM, Bastos WR (1991) Mercury dispersal in water, sediments and aquatic biota of a gold mining tailing deposit drainage in Pocone, Brazil. Water Air Soil Pollut 55:283-294

Lacerda LD (1994) Biogeochemistry of heavy metals in coastal lagoons. In: Kjerfve B (ed) Coastal lagoon processes. Elsevier Science BV, Amsterdam, The Netherlands, pp 221-241

Lau S, Mohamed M, Tan Chi Yen A, Su'ut S (1998) Accumulation of heavy metals in freshwater molluscs. Sci Total Environ 214:113-121

Luoma SN, Rainbow PS (2005) Why Is metal bioaccumulation so variable? Biodynamics as a unifying concept. Environ Sci Technol 39:1921-1931

Lwanga MS, Kansiime F, Denny P, Scullion J (2003) Heavy metals in Lake George, Uganda, with relation to metal concentrations in tissues of common fish species. Hydrobiologia 499:83-93

Marin-Guirao L, Llotet J, Marin A (2008) Carbon and nitrogen stable isotopes and metal concentration in food webs from a miningimpacted coastal lagoon. Sci Total Environ 393:118-130

Marsden ID, Rainbow PS (2004) Does the accumulation of trace metals in crustaceans affect their ecologȳthe amphipod example? J Exp Mar Biol Ecol 300:373-408

McIntyre JK, Beauchamp DA (2007) Age and trophic position dominate bioaccumulation of mercury and organochlorines in the food web of Lake Washington. Sci Total Environ 372:571-584

Mee LD (1978) Coastal lagoons. In: Riley J, Skirrow O (eds) Chemical oceanography. Academics, New York, NY, pp 441490

Menezes NA, Figueiredo JL (1980) Manual de peixes marinhos do Sudeste do Brasil. Museu de Zoologia. Universidade de São Paulo, São Paulo, Brazil

Michener RH, Schell DM (1994) Stable isotopes ratios as tracers in marine aquatic food webs. In: Lajtha K, Michener RH (eds) Stable isotopes in ecology and environmental science. Blackwell Scientific, Oxford, England, pp 138-157

Minagawa M, Wada E (1984) Stepwise enrichment of $15 \mathrm{~N}$ along food chains: further evidence and the relation between [delta] $15 \mathrm{~N}$ and animal age. Geochim Cosmochim Acta 48:1135-1140

Nauen CE (1983) Compilation of legal limits for hazardous substances in fish and fishery products. FAO Fisheries Circular 
No. 764. Food and Agriculture Organization of the United Nations, Rome, Italy

Pereira AA, Van Hattum B, Brouwer A, van Bodegom PM, Rezende CE, Salomons W (2008) Effects of iron-ore mining and processing on metal bioavailability in a tropical coastal lagoon. J Soil Sediment 8:239-252

Pinnegar JK (1999) Differential fractionation of $\mathrm{d}^{13} \mathrm{C}$ and $\mathrm{d}^{15} \mathrm{~N}$ among fish tissues: Implications for the study of trophic interactions. Funct Ecol 13:225-231

Rainbow PS (2007) Trace metal bioaccumulation: models, metabolic availability and toxicity. Environ Int 33:576-582

Rainbow PS (2002) Trace metal concentrations in aquatic invertebrates: why and so what? Environ Pollut 120:497-507

Reinfelder JR, Fisher NS, Luoma SN, Nichols JW, Wang WX (1998) Trace element trophic transfer in aquatic organisms: a critique of the kinetic model approach. Sci Total Environ 219:117-135

Sharma CM, Borgstrom R, Huitfeldt JS, Rosseland BO (2008) Selective exploitation of large pike Esox lucius-effects on mercury concentrations in fish populations. Sci Total Environ 399:33-40

Silva CAR, Rainbow PS, Smith BD, Santos ZL (2001) Biomonitoring of trace metal contamination in the Potengi estuary, Natal (Brazil), using the oyster Crassostrea rhizophorae, a local food source. Water Res 35:4072-4078

Swales S, Storey AW, Roderick ID, Figa BS, Bakowa KA, Tenakanai CD (1998) Biological monitoring of the impacts of the OK Tedi copper mine on fish populations in the Fly River system, Papua New Guinea. Sci Total Environ 214:99-111
United States Environmental Protection Agency (1989) Assessing human health risks from chemically contaminated fish and shellfish: a guidance manual. EPA-503/8-89-002. Office of Marine Protection, Washington, DC

United States Environmental Protection Agency (1998) Integrated risk information system. Available at: http://cfpub.epa.gov/ncea/ iris/index.cfm. Accessed 20 Sept 2009

Van Hattum B, Timmermans KR, Govers HA (1991) Abiotic and biotic factors influencing in situ trace-metal levels in macroinvertebrates in fresh-water ecosystems. Environ Toxicol Chem 10:275-292

Wagner A, Boman J (2003) Biomonitoring of trace elements in muscle and liver tissue of freshwater fish. Spectrochim Acta Part B At Spetrosc 58:2215-2226

Wang WX (2002) Interactions of trace metals and different marine food chains. Mar Ecol Progr Series 243:295-309

Watanabe K, Monaghan MT, Takemon Y, Omura T (2008) Biodilution of heavy metals in a stream macroinvertebrate food web: evidence from stable isotope analysis. Sci Total Environ 394:5767

Yilmaz F, Özdemir N, Demirak A, Tuna AL (2007) Heavy metal levels in two fish species Leuciscus cephalus and Lepomis gibbosus. Food Chem 100:830-835

Zuanon JAS, Pezzato AC, Pezzato LE, Passos JRS, Barros MM, Ducatti C (2006) Muscle delta C-13 change in Nile tilapia (Oreochromis niloticus): effects of growth and carbon turnover. Comp Biochem Physiol B 145:101-107 